\title{
Towards Non-Spontaneity in Interpretation of Implicature Serving Implicit Characterization: The Case of Subsidiary Trait Precipitation in Arthur C. Doyle's 'A Study in Scarlet'
}

\author{
Hammed Mohammadpanah ${ }^{1}$, Samira Hamzehei ${ }^{2}$, Lale Massiha ${ }^{1 *}$ \\ ${ }^{1}$ English Department, Faculty of Persian Literature \& Foreign Languages, University of Tabriz, Tabriz, Iran \\ ${ }^{2}$ English Department, Azad University-Marand Branch, Marand, Iran
}

Corresponding Author: Lale Massiha, E-mail: lale.massiha@ymail.com

\begin{tabular}{l} 
ARTICLE INFO \\
\hline Article history \\
Received: July 17, 2018 \\
Accepted: October 14, 2018 \\
Published: December 01, 2018 \\
Volume: 7 Issue: 7 \\
Advance access: October 2018 \\
Special Issue on Language \& \\
Literature
\end{tabular}

Conflicts of interest: None Funding: None

\begin{abstract}
Although characterisation is a much-aged matter in literature, certain aspects have yet to be explored, such as how fictional characters implicate in their discourse, what takes influence from this, and what comes to pass in the production and interpretation process of the phenomenon. As the contribution is of subtlety, implicata in characters' discourse have not exclusively been studies in detail as elements of characterisation. Therefore, in view of the cognitive approach leant towards by leading researchers on the subject of characterization such as Jonathan Culpeper, this research relies on Sperber and Wilson's 'relevance theory' to define cognitive procedures into instances of implicata verbally exchanged between fictional characters to determine a) how authors exploit such instances for trait progression of their characters and upholding character discourse credibility, and b) how readers can achieve what Furlong terms a 'non-spontaneous' interpretation of such exchanges. To address the stated issue, we conducted a detailed cognitiveeffectual analysis on five instances of implicata made by four flat and round characters within Arthur C. Doyle's 'A Study in Scarlet', the results of which yielded a mechanism wherein writers' making implications and readers' calculating and interpreting them hinge on both parties making presuppositions on certain topics to ensure certain pragmatic presuppositional effect for readers. A five-stage bottom-up process was also proposed which links character traits to implications conveyed within inter-character discourse, following through which can lead to readers' achieving maximal relevance on the made implications and a non-spontaneous interpretation of them.
\end{abstract}

Key words: Implicature, Presupposition, Characterization, Non-spontaneous Interpretation, Relevance Theory

\section{INTRODUCTION}

That the language of literature is to be treated differently than are other forms of discourse has been under constant debate for many decades. After a mere glimpse at what stylistic analyses on various works of literatures offer as output, one cannot help agreeing and disagreeing to the variance in treatment. On the one hand, it would be literally impractical to deny the singularity in the production and interpretation of literary discourse for reasons such as the non-spontaneity involved in the production. On the other, it is also impractical, perhaps more convincingly so, to resist analyzing literary discourse in the same light as one does the everyday more spontaneously-exchanged discourse, particular to which are the utterances exchanged in the course of everyday conversations held between interlocutors in countless varying contexts. Such conversations are deemed to be the most authentically-originated forms of language. In whatever way compared to the latter utterances, the utterances made by characters cannot possibly be considered lacking authenticity. This very presumption alone does well enough to rouse curiosity towards one curiously interesting question seeking what results might issue were the same scope (literature) subjected to a pragmatically-based analysis.

One needs very little inspiration for such curiosity, for unless we assume that inter-character conversations occurring within literary discourse are totally unrelated to real-life discourse, we will find it irrefutable that they follow and comply, to a tenable extent, with the same patterns and norms as do real-life conversations. Though they cannot arguably be considered as totally 'authentic', it does not necessarily make them any less than derivational imitations of real-life discourse. Were it otherwise, they would not be much more than hindrance in the way of readers' comprehension, making it impossible to tag along and click with the characters and the narrative. This justifies attempts to delineate the pragmatics of literary discourse such as those by Furlong (1996), Chapman and Clark (2014) and many others. However, many aspects still remain un- or underexplored.

Applying various pragmatic theories unto literary discourse, as another complement to the Russian Formalist Ap- 
proach, has and can, for many years to come, prove to be enlightening in many respects. For one, as this research will attempt to argue, it can be not only informative as to how inter-character conversations work, but also encouragingly edifying as to how authors employ such pragmatic devices to deepen their characterization and also develop their narratives. Not being able to place in the light the ways character speech determines, in its own turn, how a fictional character is characterized can be troubling. However, this is a largescale question with multiple aspects to it, which is why we focus our research on the implicit side of characters' speech. In order to account for what causes characters to appear as explicit/implicit as they do at any sample of their utterance-making, two pragmatic sub-areas, namely 'implicatures' and 'presuppositions', demand to be looked into as the issue is, at one of its recesses, rooted in pragmatics.

Even without having technically investigated the phenomena sample by sample, it would sound reasonably safe to accept the fact that implication within character speech is another layer of implicitly presenting information about a character. However, generalities of this kind have to be pinned on specificities, which is why this research aims to establish the possibility of such a linkage between implicata made by characters, their intentions, their traits and the overall character and defining it. For that, characters' personal traits must be accounted for on every occasion the author attempts to introduce or alter their traits though implications within their speech. In addition to an exploration of characters' traits, this research further aims to explore the occurrences in the minds of authors at the time of producing the implicata through characters, and readers' minds at the time of making inferences on and interpreting them. All this is solely possible via detailed investigation, and this is precisely what this research means to undertake.

\section{LITERATURE REVIEW}

The concept of implicature is generally agreed on to account for what is communicated though not said. Various sources (e.g., Cruse, (2000); Portner, 2006; Schmitt, 2010; Thomas, 2013, Yule 1996) offer accounts of it In a prototypical format, the concept of implication was addressed by Grice and White (1961), and was later developed in Grice's renowned Cooperative Principle of communication and the four main maxims of cooperative communication proposed within For Grice (1991), as opposed to a 'conventional' one, an intended 'conversational implicature' would appeal heavily to the immediate context available to the interlocutors, the common ground shared by them, as well as any sort of flouting any of the four main maxims and the sub-maxims which would fall under them. However, a speaker's flouting any of the maxims would not necessarily mean for the hearer to disregard the utterance altogether as irrelevant. As an authoritative Neo-Gricean, Levinson (1983) states that "in most ordinary kinds of talk these principles are oriented to, such that when talk does not proceed according to their specifications, hearers assume that, contrary to appearances, the principles are nevertheless being adhered to at some deeper level" (Levinson, 1983, p. 102). Levinson (1983) also highlights Grice's awareness of intentional violations as he believes that his argued position does not stipulate speakers' constant adherence to the maxim, even on a superficial level at times, but of hearers' interpretation of what is uttered as conforming to the maxims on at least some level.

As logically tenable as the processes of maxim-flouting were, with the advent of Post-Gricean views, the Gricean view on 'implicature' along with $\mathrm{CP}$ itself underwent a few major revamps and revisions, the biggest and probably the most influential of which coming from Sperber and Wilson in their Relevance Theory. As a major overhaul to Grice's $\mathrm{CP}$ and $\mathrm{CP}$-oriented pragmatic devices, RT brought on a new viewpoint towards implicature as well. To Sperber and Wilson (1995), implicatures are not merely caused by violating maxims, as they did to Grice. To them, implicature as defined by Grice fell short of a full coverage of matters such as speaker preference, speaker inability, and speaker unwillingness, inferential skills and most importantly the presence of relevance.

Sperber and Wilson (1995) mention certain conditions for the sustenance of relevance such as guaranteed contextual effect achieved as a result of the processing, and the optimal effect at the cost of minimal effort. For a brief account of the fundamental principles of relevance, Sperber and Wilson (2006) can be resorted to. In their account of how relevance is achieved in communication, Sperber and Wilson emphasize the role of context and human cognition in the process of human comprehension by describing the phenomenon in terms of 'processing effort' and 'cognitive effect', which appears to be a much refined and more comprehensive delineation.

According to relevance theory, an input is relevant to an individual when its processing in a context of available assumptions yields a positive cognitive effect. A positive cognitive effect is a worthwhile difference to the individual's representation of the world: a true conclusion, for example. False conclusions are not worth having; they are cognitive effects, but not positive ones (Sperber and Wilson, 2006, p. 608).

Simplistically speaking, Sperber and Wilson believe that 'cognitive effect' is only caused when there is a conclusion for the human mind to reach, and only when it does so is cognitive effect produced and relevance achieved. The most important type of cognitive effect, as proposed by Sperber and Wilson (2002), is contextual implication, defined as "a conclusion deducible from input and context together, but from neither input nor context alone".

Though it only takes a fraction of a second, our minds do not take a mere direct route towards conclusions so as to achieve the all-important effect. There are different layers to human comprehension process, and conclusions are part of them. As suggested in Sperber and Wilson (1995, 2002), processing of conclusions, which occurs after processing the explicit layer, is dealt with in two sub-layers. Taking a relevance-theoretic point of view, once an utterance is made - or, in more precise terms, a message is delivered through verbal or non-verbal communication - in order to conduct the task of recovering as much of the speaker-intended interpretation as possible, the hearer has to follow through three cognitively stipulated sub-tasks: 
a. Constructing an appropriate hypothesis about explicit content (explicatures) via decoding, disambiguation, reference resolution, and other pragmatic enrichment processes

b. Constructing an appropriate hypothesis about the intended contextual assumptions (implicated premises)

c. Constructing an appropriate hypothesis about the intended contextual implications (implicated conclusions) (Sperber and Wilson, 2002)

Appealing to the gradeability of their nature, Sperber and Wilson (1995) further categorize implicated propositions into strongly implicated (strong implicature) - recovery of which is essential for the hearer's arriving at an interpretation which satisfies their expectations of relevance - and weakly implicated (weak implicature) - recovery of which helps, but is not essential for such an interpretation as any among the range of similar possible implicatures offered would be satisfactorily helpful.

With the classifications above in the matter of communication, implication and interpretation, though RT has been successful enough in patching up what $\mathrm{CP}$, even with its later Neo-Gricean updates of relativity maxims, fell short of evincing in as all-round a way as RT, it would seem more prudent for an analysis to take advantage of instances on which the two concur, and realize how each would fare were a literary context to come into play.

In addition to the binary accounts of the implication, the presuppositional phase is a factor as well in the process of implicating. As this research makes an attempt to arrive at intentions and presuppositions behind characters' implicating in their speech, presupposing is key to any process which means to deal with what precedes the act of making utterances, weather conveying messages implicitly or explicitly. Unless the intention drive and presuppositional phase dictate, no utterance is made and no proposition conveyed. On the criticality of the presuppositional phase for implication, Blackmore (1992) argues that:

speakers make decisions not only about whether what they want to communicate is to be explicated or implicated, but also about the extent to which they will constrain the hearer's recovery of implicatures. Clearly, this decision too will be affected by the speaker's estimation of the hearer's contextual and processing resources. (Blackmore, 1992, p. 131).

Sperber and Wilson (1995), as well, emphasize the role of a background stage to implication by their assumption that "a crucial step in the processing of new information, and in particular of verbally communicated information, is to combine it with an adequately selected set of background assumptions" (Sperber and Wilson, 1995, p. 138).

As an accompaniment to the discursive side discussed so far, there is need here to define, as utterance-makers in literary texts, characters through which authors develop conversations in their works. As Martin (2004) and McKee (1997) suggest, the process of building characters is a remarkably intricate one, one major source of intricacy being that of the character's speech. The parameters of this research emphasize the influence trade between what a character implicates in his/her speech and how s/he is characterized. To determine the how of such characterization, it is imperative that we determine the linkage between the implicatures within a character's speech and his/her 'traits' as building blocks by which the 'character' is defined. Roberts (1995), defining a character as "a verbal representation of a human being", suggests, for the purpose of studying literary characters, determining the character's outstanding traits.

A trait is a quality of mind or habitual mode of behavior such as never repaying borrowed money, avoiding eye contact, or always thinking oneself the center of attention. Sometimes, of course, the traits we encounter are minor and therefore negligible, but often a trait may be a person's primary characteristic. (Roberts, 1995, p. 61-62).

Integrality of character speech to character traits and characterization is beyond questioning. Technically, sources of trait-devising number a few. Rimmon-Kenan (2005) suggests four main sources for characterization, a) speech, b) action, c) external appearance, d) environment. As an inseparable facet to characterization, "a character's speech, whether in conversation or as a silent activity of the mind, can be indicative of a trait or traits both through its content and through its form" (Rimmon-Kenan, 2005, p. 65). The term 'speech' here does not represent solely utterances made by the character him/herself. One additional level of speech-oriented characterization comes from other characters' utterances and impressions about the character under focus. As a leading figure in the field of characterization, Culpeper (2001) talks of self-presentation, where "a character or person provides explicit information about him or herself," and other-presentation, where "a character or person provides explicit information about someone else" (Culpeper, 2001, p. 167). It stands to reason that both sub-categories are fundamental for a research dealing with mainly with character speech as the material for analysis.

As a further sub-categorization also applicable to character discourse, it has been argued by Eder et al. (2010) that one way of dividing characterization cues is by the degree of explicitness/implicitness in them, where explicit cues name the trait explicitly whereas implicit cues present the trait in an indirect fashion. As the terms 'implication' and 'implicature' overtly suggest, most, not to say every, trait transaction attributable to them are bound to belong to the second group. Given the context and speaker preference and ability, what the speaker decides to impart - including the traits their utterances lead to - as strongly and weakly implicated, if pointed out, could be a strong lead towards the intention behind the utterance. With 'intention' among the six contextual aspects of utterers' 'mental world' - emotion, belief, desire, wish, intention, motivation - listed by Verschueren (2003), it is only natural that character intention behind any instance of character verbal implication occupies an undeniable portion of the focus in this research, an inclusion further supported by Johnstone's (2008) account of context and its aspects.

Viability is due for pointing out the intentions behind implications, for as we are told by Davis (1998), there exists an 'invitation' for the hearer to visit and interpret implicatures. 
However, as to what this 'invitation' calls for, one of the most convincing arguments is set forth by Furlong (1996), originally proposing readers' achieving a higher level of relevance on a literary text than the optimal relevance meant to be achieved for a spontaneous interpretation. which she terms 'maximal' relevance which is meant by authors of literary texts for the reader to achieve. The means of achieving such relevance is catered through what Furlong (1996) calls 'non-spontaneous interpretation'. The view towards character-made implication proposed by this research promises great potential of vitality for a non-spontaneous interpretation of character speech.

\section{METHODOLOGY}

To arrive at character traits through the implicata in a character's verbal discourse, as part of character speech, we conducted a five-stage analysis on five instances of implicata made by Arthur C. Doyle through four characters to as a means of self- or other-representation to further characterize four characters in Doyle's 'A Study in Scarlet'. As the initial step, major contextual specifications were accounted for, as readers deal essentially with contextualized conversations in most narratives. Participants, spatial and temporal settings, and the main topic of conversation were the particular specifications dealt with. Following this, two expository treatments of the implicata were administered. First, speaking in Gricean terms, the maxims (Note 1) which were flouted (Note 2) by implicating at each sample were noted. Then the implicature sample was accounted for in relevance-theoretic terms under three sub-parts

\footnotetext{
A Implicated premises: assumptions out of semantic and pragmatic contexts, essential for building implicated conclusions on

B Strongly implicated conclusions: conclusions essential for achieving optimal relevance and stoppage of processing effort for the reader's spontaneous interpretation - bearing major positive cognitive effect

C Weakly implicated conclusions: conclusions essential for achieving maximal relevance and stoppage of processing effort for the reader's non-spontaneous interpretation - bearing minor cognitive effect
}

Drawing a line between what is weakly implicated and what is an implicated premise for such conclusions comes down to the role of the pragmatic context and how strong a contextual effect it imposes. This is for the simpler reason that weak implicata rely so heavily on the hearer/reader's (Note 3) inferencing and what Sperber and Wilson (1995) call 'mutual manifestness', which comes about when interlocutors manifestly share cognitive environments. Such heavy use of the unsaid for their calculation makes the cognitive effect produced by them so strong as to drive us into considering them one tier above the others, though the gradation among them is still unfixed and prone to change.

Subsequent to the implication tiers, particular grounds of presuppositional phase assumptions were outlined on which certain presuppositions had been made by the writer and were expected by him of the reader to make. The expectation is due as making the expected presuppositions by the reader is crucial for striking the mutual manifestness of the implications between the two minds. Not even optimal relevance would be achievable to the reader without settling this level of understanding, hence the criticality.

Once in the presuppositional phase, assumptions may be sub-divided based on which presupposition type they fall under. However, listing precise presuppositions in the sense that they are attached to an utterance is a blurry terrain indeed to tread into. Categorizations, be they Gricean, neo-, or post-Gricean, vary considerably, particularly due to their much-debated reducibility to implicatures. One could vision them as an exclusively syntactically-triggered phenomenon, or argue in favor of the complementation of such 'semantic presuppositions' by 'pragmatic presuppositions'. It has been argued that if we are to assume that 'semantic presuppositions' are attached to and ruled by syntactic and lexical triggers, then the presuppositions to be triggered by the interlocutors' mutual manifestness and the pragmatic context are treated as 'pragmatic presuppositions'. Tenably, the fact that the lexical and syntactic build of an utterance fail to trigger an assumption outside the given context cannot denote absence of the assumption as a presupposition once the utterance is contextualized. Even then, we can assume that not all pragmatic presuppositions share the same level of significance when pragmatic context and speaker/writer's communicative intents, preferences and goals are considered.

Not quite contrary to the above classification, one noteworthy alternative typological account of them comes from Beaver (2001) and his distinction of 'potential' from 'actual presuppositions' where "calculation of the potential presuppositions is semantic (since it is assumed to depend on the details of specific lexical items and syntactic structures), but calculation of the actual presuppositions is pragmatic" (Beaver, 2001, p. 84). That Beaver's account of actual presupposition is of a pragmatic basis, considering them as closely related to 'pragmatic presuppositions' would hardly be going astray.

Though we face a variety of classifications as to pinpoint what is presupposed by the speaker/writer, yet making a list of precise presuppositions and making subsequent deductions would make too subjective a treatment of the phenomenon. Therefore, what we observed were the specific grounds of presuppositional phase assumptions (Note 4) making presuppositions on which was essential for the reader in order to achieve maximal relevance and a non-spontaneous interpretation of the implications made by the writer/character (Note 5).

With the presuppositional phase dealt with, a list was made of the various traits the author has addressed through the instance of implicating through the character. This addressing involves helping (Note 6) specific traits be introduced, supported (strengthened), downplayed (weakened), or transformed.

\section{ANALYSIS AND RESULTS \\ Sample 1 - Chapter One: "Mr. Sherlock Holmes" - para. 27}

One of the first occasions of implicata exchange occurs very early on in the narrative between Doctor John Watson and 
an acquaintance of his by the name of Stamford. Watson is back in London seeking rental residence. Since the prices do not tally with his wallet, he remains a home-seeker for the moment. Stamford, knowing of Watson's predicament, suggests to him Mr. Sherlock Holmes, whom to his knowledge is in search of someone to go halves with in renting a decent apartment he has been lucky enough to locate. The following piece of conversation occurs when Stamford tries to present to Watson what kind of a personality Sherlock Holmes is of.

Watson: "If we don't get on it will be easy to part company," I answered. "It seems to me, Stamford," I added, looking hard at my companion, "that you have some reason for washing your hands of the matter. Is this fellow's temper so formidable, or what is it? Don't be mealy-mouthed about it."

Stamford: "It is not easy to express the inexpressible," he answered with a laugh. "Holmes is a little too scientific for my tastes - it approaches to cold-bloodedness. I could imagine his giving a friend a little pinch of the latest vegetable alkaloid, not out of malevolence, you understand, but simply out of a spirit of inquiry in order to have an accurate idea of the effects. To do him justice, I think that he would take it himself with the same readiness. He appears to have a passion for definite and exact knowledge (Tables 1-4)."

Essential presuppositional grounds for reader's interpretation of sample 1 implications:

a) Introduction among humans

b) Renting houses

c) Sharing houses

d) Studying and research

e) Possibility of humans posing threats to one other

f) Poisoning

g) Inquisitiveness of the human mind

Through Stamford's impression and description of Sherlock Holmes and the implication in his utterance, we are given a preliminary impression of him via this sample helping introduce into Holmes' character the trait of being 'extraordinary'. As an instance that exemplifies characteri-

Table 1. Contextual specifics of sample 1

\begin{tabular}{ll}
\hline Participants & $\begin{array}{l}\text { a. Doctor John Watson: Ex-military medic, } \\
\text { wounded and extricated from service back in } \\
\text { London } \\
\text { b. Stamford: Ex-dresser under Watson at Bart's }\end{array}$ \\
Spatial setting & $\begin{array}{l}\text { The criterion bar } \\
\text { Topic }\end{array}$ \\
\hline
\end{tabular}

Table 2. Maxim flouting within sample 1 implications

\begin{tabular}{ll}
\hline Flouted maxims & Justifications \\
\hline Quality & $\begin{array}{l}\text { Stamford does not really believe it to be } \\
\text { inexpressible. He emphasizes it as very } \\
\text { difficult to explain. }\end{array}$ \\
Quantity & $\begin{array}{l}\text { Stamford description of Holmes is too } \\
\text { long compared to the more direct way of } \\
\text { putting adjectives to him. }\end{array}$ \\
\hline
\end{tabular}

zation through other-presentation, this sample creates certain expectations as to Holmes' character, awaiting to be built on later in the narrative. This urges the need and excitement for the first encounter. It can be seen here that although the characterisation is achieved by means of others' implicit commentary on Holmes' character, it does not make this sample any less a subtle use of character discourse implications towards deeper characterization.

Table 3. Relevance-theoretic classification of sample 1 implications

\begin{tabular}{|c|c|}
\hline & Implicated premises \\
\hline 1 & Holmes' character is inexpressible. \\
\hline 2 & Holmes has a set of values like any other human being. \\
\hline 3 & $\begin{array}{l}\text { A person with a normal (generally acceptable) set of } \\
\text { values would not give his friend the vegetable alkaloid. }\end{array}$ \\
\hline 4 & $\begin{array}{l}\text { Being cold-blooded (in the figurative sense) is a human } \\
\text { quality. }\end{array}$ \\
\hline 5 & The vegetable alkaloid is detrimental to the human body. \\
\hline 6 & $\begin{array}{l}\text { As opposed to giving the fatal alkaloid to a friend on } \\
\text { educational grounds, there is another sort of readiness, } \\
\text { that of taking it yourself on the same grounds. }\end{array}$ \\
\hline 7 & Holmes has a spirit of enquiry. \\
\hline 8 & Inaccurate ideas are not desirable to Holmes. \\
\hline \multirow[t]{2}{*}{9} & $\begin{array}{l}\text { Stamford is aware of the possible consequences of } \\
\text { Watson and Holmes coming together. }\end{array}$ \\
\hline & Strongly implicated conclusions \\
\hline 1 & $\begin{array}{l}\text { Holmes' set of values differ from those of a normal } \\
\text { person. }\end{array}$ \\
\hline 2 & Being cold-blooded is not a positive quality. \\
\hline 3 & Holmes's spirit of enquiry is virtually insatiable. \\
\hline 4 & $\begin{array}{l}\text { Holmes conforms to both patterns of readiness: giving } \\
\text { the fatal alkaloid to his friends on educational grounds, } \\
\text { and taking it himself on the same grounds. }\end{array}$ \\
\hline 5 & $\begin{array}{l}\text { One's taking the same poison which he would give his/ } \\
\text { her friends mitigates the cold-bloodedness. }\end{array}$ \\
\hline 6 & $\begin{array}{l}\text { Someone who would give his friend the alkaloid might } \\
\text { not be the best choice as a house-sharing partner. }\end{array}$ \\
\hline 7 & $\begin{array}{l}\text { Holmes is not the best of choices for a house-sharing } \\
\text { partner. }\end{array}$ \\
\hline \multirow[t]{2}{*}{8} & $\begin{array}{l}\text { Stamford is not an unfair person in his remarks on other } \\
\text { people. }\end{array}$ \\
\hline & Weakly implicated conclusions \\
\hline 1 & $\begin{array}{l}\text { There is a considerable probability that Watson will be } \\
\text { surprised by Holmes. }\end{array}$ \\
\hline 2 & $\begin{array}{l}\text { Holmes' virtually insatiable spirit of enquiry surpasses } \\
\text { normality and makes him too keen on acquiring the } \\
\text { accurate ideas on his sought-after knowledge. }\end{array}$ \\
\hline 3 & $\begin{array}{l}\text { Watson had better be wary of his choice of Holmes as a } \\
\text { house-sharing partner. }\end{array}$ \\
\hline 4 & $\begin{array}{l}\text { Stamford is more keen than Watson thinks on not } \\
\text { taking the responsibility of you Watson being stuck in a } \\
\text { potentially entangling situation in his future transactions } \\
\text { with Holmes, as Watson has already accused him of } \\
\text { washing his hands of the matter. }\end{array}$ \\
\hline
\end{tabular}


Sample 2 - Chapter One: 'Mr. Sherlock Holmes' - para. 36-38

This sample also comes about early, following the previous sample fairly closely. After getting Watson's agreement to meeting Holmes, Stamford brings Watson and Holmes together for the purpose of introduction. Thereupon, the two meet for the first time, resulting in them exchanging their first ever words.

Stamford: "Dr. Watson, Mr. Sherlock Holmes," said Stamford, introducing us.

Holmes: "How are you?" he said cordially, gripping my hand with a strength for which I should hardly have given him credit. "You have been in Afghanistan, I perceive."

Watson: "How on earth did you know that?" I asked in astonishment (Tables 5-8).

Essential presuppositional grounds for reader's interpretation of sample 2 implications:

a) Process of humans' drawing conclusions and making conjectures

b) Human concept of self-esteem and self-image

c) Human boastfulness

d) Making first impressions

e) Travelling

There are multiple potential traits involved here. With the previous sample, being 'extraordinary' was introduced into Sherlock Holmes' character through Stamford's description

Table 4. Trait progression for sherlock holmes through sample 1

\begin{tabular}{|c|c|c|c|c|}
\hline \multicolumn{5}{|c|}{ Process } \\
\hline \multirow{2}{*}{ : } & Introduced & Weakened & Strengthened & Transformed \\
\hline & Extraordinary & & & \\
\hline
\end{tabular}

Table 5. Contextual specifics of sample 2

\begin{tabular}{ll}
\hline Participants & $\begin{array}{l}\text { a. John watson } \\
\text { b. Stamford } \\
\text { c. Sherlock Holmes: high-functioning } \\
\text { ingenious consultant detective, formerly } \\
\text { described, by Stamford to Watson, as a } \\
\text { peculiar science enthusiast }\end{array}$ \\
& $\begin{array}{l}\text { Chemical laboratory of a hospital where } \\
\text { Spatial }\end{array}$ \\
setting & $\begin{array}{l}\text { Holmes is about his business of chemical } \\
\text { experiments, bent on making a very significant } \\
\text { medico-legal discovery }\end{array}$ \\
& $\begin{array}{l}\text { Watson and Holmes being introduced to one } \\
\text { Topic }\end{array}$ \\
&
\end{tabular}

Table 6. Maxim flouting within sample 2 implications

\begin{tabular}{ll}
\hline Flouted maxims & Justifications \\
\hline Relation & $\begin{array}{l}\text { Holmes utters something seemingly } \\
\text { irrelevant to the present subject. }\end{array}$ \\
Manner & $\begin{array}{l}\text { Holmes could have conveyed a few } \\
\text { other pieces of information before } \\
\text { telling the doctor where he had been. } \\
\text { The submaxim of being orderly is } \\
\text { flouted. }\end{array}$ \\
\hline
\end{tabular}

of him and via other-representation. This is our first encounter with him, and through his own discourse (self-representation) here, not only has being 'extraordinary' been supported and strengthened, other traits have also been added, as those of being 'ingenious', 'confident' and 'showy' are helped become introduced.

\section{Sample 3 - Chapter Three: 'The Lauriston Garden Mystery' - para. 14-16}

This sample is exchanged between Holmes and Watson a while after their joining together in their new home, with

Table 7. Relevance-theoretic classification of sample 2 implications

\begin{tabular}{|c|c|}
\hline & Implicated premises \\
\hline 1 & Watson has travelled before. \\
\hline 2 & Watson has been abroad. \\
\hline 3 & $\begin{array}{l}\text { It is not ordinary for a stranger to know such details about } \\
\text { one. }\end{array}$ \\
\hline 4 & $\begin{array}{l}\text { It is possible for Watson to assumedly guess someone has } \\
\text { told Holmes of his past. }\end{array}$ \\
\hline \multirow[t]{2}{*}{5} & $\begin{array}{l}\text { It is possible for Watson to assumedly guess this is only a } \\
\text { lucky guess. }\end{array}$ \\
\hline & Strongly implicated conclusions \\
\hline 1 & $\begin{array}{l}\text { It is not very common for someone such as Watson to } \\
\text { have travelled to Afghanistan. }\end{array}$ \\
\hline 2 & $\begin{array}{l}\text { It is possible for Watson to assumedly guess that Holmes' } \\
\text { surmise is too accurate to be a lucky guess. }\end{array}$ \\
\hline 3 & $\begin{array}{l}\text { It is normally uncommon and challenging for someone to } \\
\text { guess another having travelled to Afghanistan. }\end{array}$ \\
\hline 4 & $\begin{array}{l}\text { It is surprising for someone to be that sure of such a } \\
\text { long-shot deduction. }\end{array}$ \\
\hline 5 & $\begin{array}{l}\text { Watson's being surprised to hear Holmes give him such a } \\
\text { detail is warranted. }\end{array}$ \\
\hline 6 & $\begin{array}{l}\text { It is common for Holmes to deduce such detailed aspects } \\
\text { in others too early in conversation. }\end{array}$ \\
\hline 7 & Such a deduction is not long-shot for Holmes. \\
\hline \multirow[t]{2}{*}{8} & $\begin{array}{l}\text { It takes a substantial level of intelligence for a stranger to } \\
\text { arrive with such surety at such a long-shot deduction by } \\
\text { merely observing someone. }\end{array}$ \\
\hline & Weakly implicated conclusions \\
\hline 1 & Holmes has considerable confidence in his speculations. \\
\hline 2 & $\begin{array}{l}\text { Holmes does possess the substantial level of intelligence } \\
\text { required of a stranger to deduce where one has been by } \\
\text { merely observing them. }\end{array}$ \\
\hline
\end{tabular}

Table 8. Trait progression for Sherlock Holmes through sample 2

\begin{tabular}{|c|c|c|c|c|}
\hline \multicolumn{5}{|c|}{ Process } \\
\hline \multirow{4}{*}{. } & Introduced & Weakened & Strengthened & Transformed \\
\hline & Ingenious & & Extraordinary & \\
\hline & Confident & & & \\
\hline & Showy & & & \\
\hline
\end{tabular}


Watson getting to know more and more of his house-mate. Upon receiving a help request from Tibias Gregson of the Scotland Yard, Holmes asks Watson to read him the request letter out loud. The letter tells of a case which appears of unique unravellability. This is taken by Gregson to arouse Holmes' interest. And of course need is there for Holmes to shed some light onto the matter. But Holmes is not so heedful of the urgency and addresses Watson with an unexpected remark.

Holmes: "Gregson is the smartest of the Scotland Yarders," my friend remarked; "he and Lestrade are the pick of a bad lot. They are both quick and energetic, but conventional-shockingly so. They have their knives into one another, too. They are as jealous as a pair of professional beauties. There will be some fun over this case if they are both put upon the scent."

Watson: I was amazed at the calm way in which he rippled on. "Surely there is not a moment to be lost,"

I cried, "Shall I go and order you a cab?"

Holmes: "I'm not sure about whether I shall go. I am the most incurably lazy devil that ever stood in shoe leather-that is, when the fit is on me, for I can be spry enough at times (Tables 9-12)."

Essential presuppositional grounds for reader's interpretation of sample 3 implications:

a) Human intelligence

b) Human boastfulness

c) Justice system and police force

d) Crime

e) Humans' assistance to one another

Drawing on all characterizational elements for Sherlock Holmes so far, particularly his actions and speech, all the five traits involved here, those of being 'showy', 'confident', 'stubborn', 'sanctimonious' and 'self-centered', have already been introduced into his character prior to this point and are further reinforced here. We have already come to view him this way, deservedly or un- depending on the reader's point of view, yet are continually implicitly reminded of his egotistical nature by instance of implicating such as this.

Table 9. Contextual specifics of sample 3

\begin{tabular}{ll}
\hline Participants & $\begin{array}{l}\text { a. John watson } \\
\text { b. Sherlock Holmes }\end{array}$ \\
Spatial setting & $\begin{array}{l}\text { Holmes and Watson's newly-rented apartment, } \\
\text { Baker Street }\end{array}$ \\
Topic & $\begin{array}{l}\text { Gregson of Scotland Yard writing to and } \\
\text { asking Holmes for assistance on a puzzling } \\
\text { murder case }\end{array}$ \\
\hline
\end{tabular}

Table 10. Maxim flouting within sample 3 implications

\begin{tabular}{ll}
\hline Flouted maxims & Justifications \\
\hline Quality & $\begin{array}{l}\text { Holmes does not literally mean that the whole } \\
\text { Scotland Yard force is bad. }\end{array}$ \\
Quality & $\begin{array}{l}\text { Holmes is not truly uncertain about his choice } \\
\text { of attending the murder scene. }\end{array}$ \\
\hline
\end{tabular}

\section{Sample 4 - Chapter eight: 'On the Great Alkali Plain'- para. 12 - 14}

This next sample closely follows the major flashback in the narrative. After a Jefferson Hope is quite suddenly and surprisingly introduced as the sought-after perpetrator of two murders by Sherlock Holmes, the second part of the

Table 11. Relevance-theoretic classification of sample 3 implications

\section{Implicated premises}

1 Both Holmes and Watson have the same basic conception of what Scotland Yard is and does.

2 Holmes intends for Watson to assume that there is a possibility that he will go to the crime scene.

3 Holmes intends for Watson to assume that there is a possibility that he will not go to the crime scene.

4 Scotland Yarders do not appeal to Holmes.

5 Gregson and Lestrade are different from other Scotland Yarders.

6 Holmes has a thirst for solving mysterious crimes.

7 The crime spoken of which interests Watson greatly, does not interest Holmes as much as it does Watson.

\begin{tabular}{|c|c|}
\hline & Strongly implicated conclusions \\
\hline 1 & $\begin{array}{l}\text { Holmes intends for Watson to assume that the possibility } \\
\text { of Holmes not going to the crime scene is greater than the } \\
\text { possibility of him going. }\end{array}$ \\
\hline 2 & $\begin{array}{l}\text { Scotland Yarders are mostly not as clever and } \\
\text { quick-witted as is expected of them. }\end{array}$ \\
\hline 3 & $\begin{array}{l}\text { By Holmes' standards, Gregson and Lestrade stand out } \\
\text { amongst the (are different from other) Scotland Yarders in } \\
\text { a positive sense. }\end{array}$ \\
\hline 4 & The smartest of Scotland Yarders seek Holmes' help. \\
\hline 5 & $\begin{array}{l}\text { Holmes can solve problems which beat the smartest of } \\
\text { Scotland Yarders. }\end{array}$ \\
\hline 6 & $\begin{array}{l}\text { Holmes is only interested in the most indecipherable of } \\
\text { crimes. }\end{array}$ \\
\hline \multirow[t]{2}{*}{7} & $\begin{array}{l}\text { The crime spoken of is not mysterious and challenging } \\
\text { enough to interest Holmes. }\end{array}$ \\
\hline & Weakly implicated conclusions \\
\hline 1 & Holmes is smarter than the smartest of the Scotland Yard. \\
\hline 2 & $\begin{array}{l}\text { Holmes' thirst for solving mysterious crimes is } \\
\text { exceedingly more difficult to appease than that of others. }\end{array}$ \\
\hline
\end{tabular}

Table 12. Trait progression for sherlock holmes through sample 3

\begin{tabular}{|c|c|c|c|c|}
\hline \multicolumn{5}{|c|}{ Process } \\
\hline \multirow{6}{*}{. } & Introduced & Weakened & Strengthened & Transformed \\
\hline & & & Showy & \\
\hline & & & Confident & \\
\hline & & & Stubborn & \\
\hline & & & Sanctimonious & \\
\hline & & & Self-centered & \\
\hline
\end{tabular}


narrative commences with a move back to years ago to the extreme desert surrounding where we encounter a little girl named Lucy (as whose lover we are later introduced to Jefferson Hope). We find she is being looked after by a man we later are told is John Ferrier. The two are all that remains of a whole group. The rest of the party, including Lucy's family, have recently been claimed by the desert. John Ferrier is carrying little Lucy, giving her a better chance of staying alive saving her strength. She does not have a clear idea of what death is as of yet. $\mathrm{He}$ is totally aware of her sensitive fledgling disposition and how difficult it must have been for her. However, he is not keen on keeping her in the dark as to how matters truly stand. Verging on death as they are, they are still trying to make their last-minute efforts towards survival. This is where Ferrier puts little Lucy down, a little too rough for her taste, enough to cause a complaint. Below is how the conversation continues.

John Ferrier: "How is it now?" he answered anxiously, for she was still rubbing the towsy golden curls which covered the back of her head.

Lucy: "Kiss it and make it well," she said, with perfect gravity, shoving the injured part up to him. "That's what mother used to do. Where's mother?"

John Ferrier: "Mother's gone. I guess you'll see her before long."

Lucy: "Gone, eh!" said the little girl. "Funny, she didn't say good-bye; she most always did if she was just goin' over to Auntie's for tea, and now she's been away three days. Say, it's awful dry, ain't it? Ain't there no water, nor nothing to eat?"

John Ferrier: "No, there ain't nothing, dearie. You'll just need to be patient awhile, and then you'll be all right. Put your head up agin me like that, and then you'll feel bullier. It ain't easy to talk when your lips is like leather, but I guess I'd best let you know how the cards lie. What's that you've got?"

Lucy: "Pretty things! fine things!" cried the little girl enthusiastically, holding up two glittering fragments of mica. "When we goes back to home I'll give them to brother Bob (Tables 13-16)."

Essential presuppositional grounds for reader's interpretation of sample 4 implications:
a. Survival
b. Humans' compassion towards children
c. Human death
d. Child innocence
e. Relation between human adults and children
f. Parentage

As part of her former stage of appearance in the narrative, Lucy Ferrier's flat character is helped be characterized deeper through her speech via Sample 4. As a child in an incipient life-ending predicament, her utterances here help introduce two potential traits of being 'innocent' and 'love-thirsty' into her character. This implicit demonstration of her innocence as a child further dramatizes the unfortunate nature of the tragic end that is about to take over.
Table 13. Contextual specifics of sample 4

\begin{tabular}{ll}
\hline Participants & $\begin{array}{l}\text { a. John Ferrier: one of the two survivors of } \\
\text { the twenty-one-member party, on a journey } \\
\text { through the desert, nineteen of whom have } \\
\text { starved to death. He is now taking care of } \\
\text { little Lucy. } \\
\text { b. Little Lucy: the only other survivor of the } \\
\text { party, now under the care of John Ferrier. She } \\
\text { has lost all her family to starvation on the } \\
\text { journey they are on. } \\
\text { The Great Alkali Plain, a vast, extreme, } \\
\text { dried-out desert } \\
\text { Topic }\end{array}$ \\
& $\begin{array}{l}\text { Lucy and John's fate and their chances of } \\
\text { survival }\end{array}$ \\
\hline
\end{tabular}

Table 14. Maxim flouting within sample 4 implications

\begin{tabular}{ll}
\hline Flouted maxims & Justifications \\
\hline Quality & $\begin{array}{l}\text { Ferrier is almost certain that Lucy will not } \\
\text { be alright. }\end{array}$ \\
\hline
\end{tabular}

Table 15. Relevance-theoretic classification of sample 4 implications

\begin{tabular}{|c|c|}
\hline & Implicated premises \\
\hline 1 & Lucy is capable of being patient. \\
\hline 2 & Things have not been alright. \\
\hline \multirow[t]{2}{*}{3} & Things are not alright. \\
\hline & Strongly implicated conclusions \\
\hline 1 & $\begin{array}{l}\text { Lucy is old enough to understand the concept of patience } \\
\text { and how to be patient. }\end{array}$ \\
\hline 2 & Lucy has not been patient enough up to this point. \\
\hline 3 & $\begin{array}{l}\text { Being patient may help Lucy not realize that things are not } \\
\text { alright. }\end{array}$ \\
\hline 4 & $\begin{array}{l}\text { Ferrier and Lucy do not stand an encouraging chance of } \\
\text { survival. }\end{array}$ \\
\hline 5 & Ferrier is sensitive to Lucy's young age and innocence. \\
\hline \multirow[t]{2}{*}{6} & Ferrier feels sorry for Lucy. \\
\hline & Weakly implicated conclusions \\
\hline 1 & Ferrier is not emotionally as tough as he physically is. \\
\hline 2 & $\begin{array}{l}\text { Ferrier means to mitigate the conditions and ease Lucy } \\
\text { into inescapable death. }\end{array}$ \\
\hline
\end{tabular}

\section{Sample 5 - Chapter Thirteen: "A Continuation of the Reminiscences of John Watson, M.D.” - para. 22}

This last sample on the list occurs close to the ending. Jefferson Hope has been cunningly invited to Holmes and Watson's apartment by Holmes, has been revealed as the murderer, and handcuffed there by Holmes. He calmly consents to be transported to the police station to give a full confession. Therefore, accompanied by John Watson, who has taken such a keen interest in the case by this point, Gregson, Holmes and Hope are driven to the station by Lestrade, where Hope gives, in a surprisingly calm temperament, a fully detailed account of his ingenious plan, how he pulled 
it off, and to what end his actions were guided. Amidst his confession, he makes the following utterance.

Hope: "It don't much matter to you why I hated these men," he said; "it's enough that they were guilty of the death of two human beings - a father and a daughterand that they had, therefore, forfeited their own lives. After the lapse of time that has passed since their crime, it was impossible for me to secure a conviction against them in any court. I knew of their guilt though, and I determined that I should be judge, jury, and executioner all rolled into one. You'd have done the same, if you have any manhood in you, if you had been in my place (Tables 17-20)."

Essential presuppositional grounds for reader's interpretation of sample 5 implications:

a. Remorse

b. Crime

c. Trials of justice among human

d. Vengeance

e. Romantic affection among humans

f. Male human's protective nature towards the female

On account of Jefferson Hope being a flat character, expansion of his character through multi-dimensional traits of a progressive nature is greatly repressed. His appearance in two separate temporal phases within the narrative opens up a small crevice for small-scale maneuver on that front. Therefore, his previously-introduced traits of being 'romantic', 'methodical' and 'unforgiving' are supported at Sample 5. Yet, with a chance of receiving his speech in the present time of narration, we find that he is not the stone-cold belligerent

Table 16. Trait progression for lucy ferrier through sample 4

\begin{tabular}{|c|c|c|c|c|}
\hline \multicolumn{5}{|c|}{ Process } \\
\hline \multirow{4}{*}{ 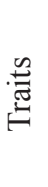 } & Introduced & Weakened & Strengthened & Transformed \\
\hline & Kind-hearted & & & \\
\hline & Practical & & & \\
\hline & Sentimental & & & \\
\hline
\end{tabular}

Table 17. Contextual specifics of sample 5

\begin{tabular}{ll}
\hline Participants & a. Jefferson Hope: He was to marry Lucy \\
& Ferrier, but his darling was stolen from him \\
& and forced to marry one Mr. Enoch Drebber \\
& who had murdered John Ferrier and taken \\
& Lucy into custody to become an eighth wife \\
& to him. Hope has avenged his long-lost love \\
by putting an end to the lives of Drebber and \\
his accomplice Mr. Stangerson, after having \\
followed them round some countries for the \\
better part of two decades. \\
b. John Watson \\
c.Sherlock Holmes \\
d. Inspector Lestrade of Scotland Yard \\
e. Inspector Gregson of Scotland Yard
\end{tabular}

homicidal maniac we have assumed him to be thus far. The implications in his utterance help introduce the as-of-now new traits of being 'reasonable' and 'civil'.

\section{DISCUSSION}

The data offered in the previous section highlights the causal transaction between the implicata made by writers of fiction within their characters' utterances and the way they are

Table 18. Maxim flouting within sample 5 implications

\begin{tabular}{ll}
\hline Flouted maxims & Justifications \\
\hline Quality & $\begin{array}{l}\text { Hope does not really believe one person } \\
\text { can be all of those at once. }\end{array}$ \\
Manner & $\begin{array}{l}\text { Hope does not keep to brevity in } \\
\text { attempting to justify his actions. }\end{array}$ \\
\hline
\end{tabular}

Table 19. Relevance-theoretic classification of sample 5 implications

\section{Implicated premises}

1 There had been a crime for there to have been guilt for committing it.

2 Any decent trial has a judge, jury, and executioner.

3 No official and decent trial with a set of judge, jury, and executioner was available for Hope.

4 It is imperative that every true man have some degree of manhood in him.

5 It is possible for Watson, Holmes, Lestrade and Gregson to visualize themselves in Hope's place.

\begin{tabular}{|c|c|}
\hline & Strongly implicated conclusions \\
\hline 1 & $\begin{array}{l}\text { Hope is not bearing any guilt about the crimes he has } \\
\text { committed. }\end{array}$ \\
\hline 2 & $\begin{array}{l}\text { Hope is aware of the procedure of an official trial and } \\
\text { there being a judge, jury, and executioner. }\end{array}$ \\
\hline 3 & Hope believes in legal trials. \\
\hline 4 & Hope has in him the manhood required of a true man. \\
\hline 5 & $\begin{array}{l}\text { Any true man must make a retaliatory attempt should } \\
\text { his beloved be wronged by the guilty hand of someone. }\end{array}$ \\
\hline 6 & $\begin{array}{l}\text { It is possible for Watson, Holmes, Lestrade and Gregson } \\
\text { to feel Hope's vengeance by visualizing themselves in } \\
\text { his place. }\end{array}$ \\
\hline \multirow[t]{2}{*}{7} & $\begin{array}{l}\text { It is possible for Watson, Holmes, Lestrade and Gregson } \\
\text { to deem Hope justified and innocent by visualizing } \\
\text { themselves in his place. }\end{array}$ \\
\hline & Weakly implicated conclusions \\
\hline 1 & $\begin{array}{l}\text { Hope is a sensible enough person to believe in a legal } \\
\text { trial Plural 's. }\end{array}$ \\
\hline 2 & Hope's retaliation was natural of his true manhood. \\
\hline 3 & $\begin{array}{l}\text { Hope was and still is convinced of the propriety of his } \\
\text { judgement of Drebber and Stangerson's guilt. }\end{array}$ \\
\hline 4 & $\begin{array}{l}\text { Inaccessibility of an official trial to Hope at the time } \\
\text { suffices to justify Hope's revengeful actions. }\end{array}$ \\
\hline 5 & $\begin{array}{l}\text { Hope intends for Watson, Holmes, Lestrade and } \\
\text { Gregson to deem him justified and innocent by } \\
\text { visualizing themselves in his place. }\end{array}$ \\
\hline
\end{tabular}


Table 20. Trait progression for Jefferson Hope through sample 5

\begin{tabular}{|c|c|c|c|c|}
\hline \multicolumn{5}{|c|}{ Process } \\
\hline \multirow{4}{*}{ 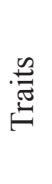 } & Introduced & Weakened & Strengthened & Transformed \\
\hline & Reasonable & & Romantic & \\
\hline & Civil & & Methodical & \\
\hline & & & Unforgiving & \\
\hline
\end{tabular}

characterized. The five samples discussed above emphasize the involvement of multiple of factors in the production of implicata by fictional characters and authors' exploitation of them. Also highlighted were certain steps taken by readers in their attempts at interpreting the various instances of implicata exchanged between characters in their discourse. That the implicated conclusions which are there for readers to draw out of what they receive from writers as material cannot be excluded from what takes place in both writers' and readers' presuppositional phases, made before giving written from to utterance on the writer's end and reading it on the reader's, was also demonstrated. Taken together, these pave the way for a number of assumptions.

\section{Production, Reception and Interpretation}

With an adherence to the claim that no implicature is made without the speaker intending to and both the speaker and hearer making certain presuppositions in the first place, we can come up with the interrelations at work when the reader chooses to spare extra processing effort to reach maximal relevance through non-spontaneous interpretation in the case of implicata within character discourse. To do so, the reader works with the material s/he is handed by the writer, namely the piece of text bearing the implications made within character discourse. What it takes for the piece to be produced and the implications to be made accounts for a major portion of the whole production half of the process. At one of the earlier stages, the writer makes his/her presuppositions as part of his/her background assumptions while expecting certain presuppositions on the part of reader. Having settled the background assumptions, the writer plans for certain implicated premises and conclusions and implicates in place of the character - Sherlock Holmes, for instance - to fulfill the aimed-for premises and conclusions. Here is where the reader makes his/her contribution. The reader receives as material the written character utterances and the implications within. S/he analyzes the written utterance, calculating as many of the intended implicated premises and conclusions as his/her inferential skills and cognitive abilities allow. It is at this stage where the efficacy of reaching maximal relevance as opposed to optimal relevance takes effect. Particularly in the case of weakly implicated conclusions is this efficacy striking, as such conclusions are the hardest to get to and require the biggest amount of processing effort. To this process of drawing conclusions, the reader brings his/ her presuppositions and the presuppositions s/he expects of the writer to have made before writing the piece of text under discussion. Also out of the calculated premises and conclusions, the reader calculates a number of the actual, not expected, presuppositions made by the writer before the written was produced. Though limited in number, the latter calculated presuppositions can help the reader with the interpretation. Through this procedure, the preliminary stages of the reader's interpretation are connected to the preliminary stages of the writer's encoding and production process, and maximal relevance is achieved for instances of implications within character discourse by the reader who is willing to spare the extra processing effort into drawing as many implicated conclusions as $\mathrm{s} / \mathrm{he}$ is able to. Figure 1 below demonstrates a clearer illustration of the overall process.

\section{Causality: From Implicata to Traits}

For the writer to make certain presuppositions and expect certain ones of the reader are definite prerequisites for making implications. However, the instances of character trait progression through implicata exchanges we documented in this paper evince that in a literary context, those are not the only steps to precede writer's production of implications in characters' utterances. Authors implicate through each character based on the feelings, communitive intents and preferences, and traits of that particular character. As a result, we can identify two major stages to come before presupposing, uttering (writing in inter-character conversation form) and implicating. Drawing on the character s/he intends to create and the traits $\mathrm{s} / \mathrm{he}$ intends to build into the character, the writer elicits from the traits certain communicative intents, preferences and goals, which drive and justify the writer/ character's presuppositions and implications within utterances as part of the character's speech. In collaboration with one another, these elements can be viewed as linked together via a five-stage causal relation which issues the bottom-up pattern illustrated in Figure 2 (Note 7).

This figure additionally shows that character traits are effectively a major direct line towards explication or implication in a character's speech and vice versa, depending on whether we picture the process through the readers' or writers' viewpoint. For a reader starting from the bottom, s/he takes the implicature s/he is given in the text and follows the steps towards the character trait(s) addressed by the sample, whereas the reverse holds true for the writer.

\section{Factors in Interpretation Non-Spontaneity}

Drawing on the steps through which our analysis was conducted, we suggest that in order for a reader to achieve maximal relevance and thus a non-spontaneous interpretation of the implicata exchanged between the characters, conscious awareness of seven aspects prove vital, where subconscious awareness of five would suffice for reaching optimal relevance and a spontaneous interpretation of the same exchange. We propose that for former deeper type of interpretation, the reader needs to be consciously aware of:

a) Contextual specifics

b) Uncooperativeness (flouting of maxims)

c) Implicated premises (quantity dictated by reader ability and preference) 


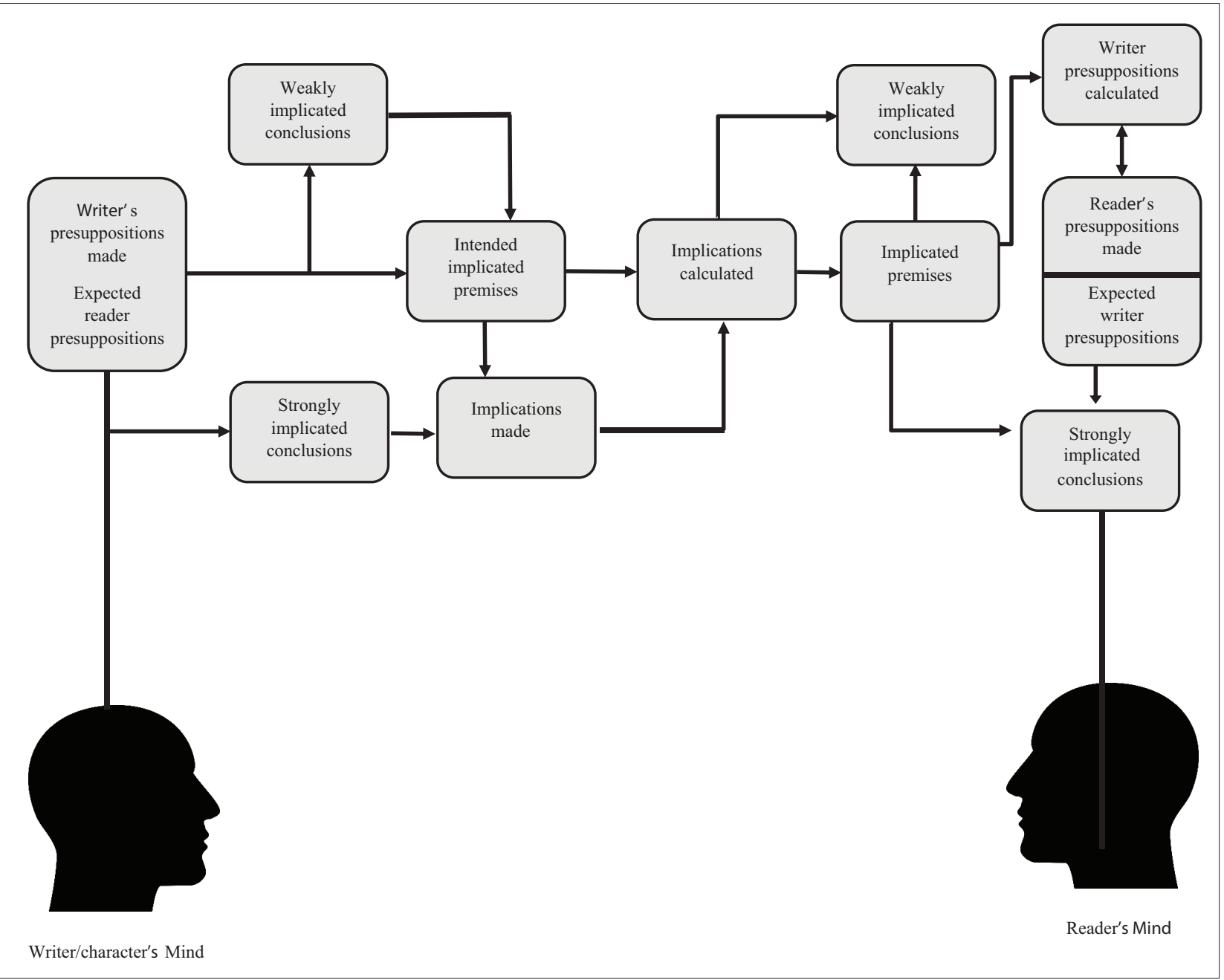

Figure 1. Non-spontaneous interpretation procedure of implications character discourse

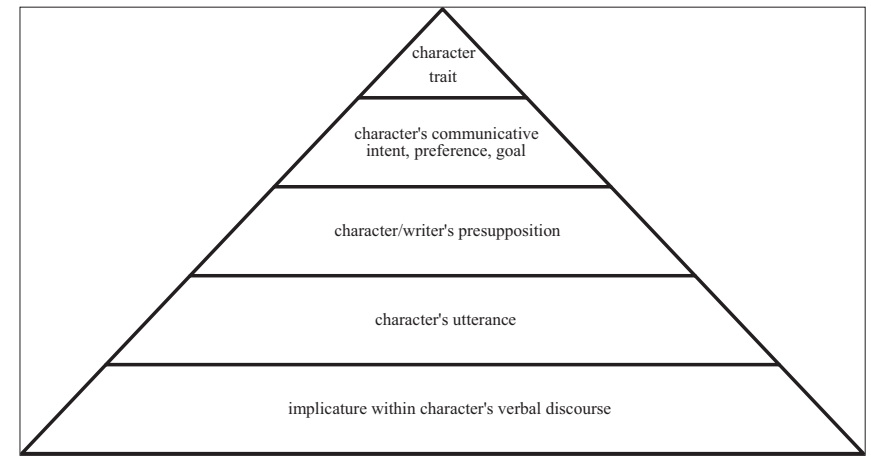

Figure 2. Causal bottom-up process for an instance of character-made

d) Strongly-implicated conclusions (quantity dictated by reader ability and preference)

e) Weakly-implicated conclusions (quantity dictated by reader ability and preference)

f) Underpinning presuppositional grounds

g) Addressed character traits

If consciously attended to by the reader, awareness of these result in more cognitive effect though at the cost of considerably more processing effort. As opposed to this case, the reader also faces the spontaneous alternative, for which awareness of (e) and (g) lose immediacy. In other words, for a spontaneous interpretation of the same exchanges, the reader need only be subconsciously aware of:

a) Contextual specifics

b) Uncooperativeness (flouting of maxims)

c) Implicated premises (quantity dictated by reader ability at the particular pace of reading)

d) Strongly-implicated conclusions (quantity dictated by reader ability at the particular pace of reading)

e) Underpinning presuppositional grounds

The latter case takes less time and processing effort on the reader's part at the cost of considerably less cognitive effect. But this is by no means to suggest that there are only two types of reading between which the reader has to choose. We need to remind ourselves of the fundamental presumption that reading is a multi-faceted relative process which can be very dynamic. A reader may choose towards which end and how far s/he moves by considering what each type offers and at what cost.

\section{CONCLUSION}

Even though they act as part of a character's speech and uphold character credibility, implicatures employed by writers 
of fiction as part of a fictional character's verbal discourse cannot merely take the exact same treatment as those occurring in spoken language, as spontaneity is not fully expected of and imposed on readers' interpretation of them. To describe their presence and role, five samples out of Arthur C. Doyle's 'A Study in Scarlet' were analysed in detail to determine a) how they are produced by authors through characters, b) what they lead to, and c) how they are interpreted in the absence of spontaneity. It was shown that authors make certain presuppositions, and also based on the communicative intents and preferences, and traits of the characters through they choose to implicate, make certain implications through certain utterances from the characters. With their own presuppositions, readers take the implicata-holding utterances in the text as material for analysis, draw not only as many implicated premises and conclusions from them as they can, but they also deduce what presuppositions were made by the author and are expected of him/her (see Figure 1). This is to say that in a literary context, due to the writer's preliminary concern and planning for them in his presuppositional assumptions and considerations, it is central for implicatures to have been thought of, hoped for and meant for as early as in the presuppositional phase of the writer giving written form to character utterances. In consequence of the writer's planning ahead, making certain presuppositions and expecting some on the part of the reader are partly responsible for triggering implicated premises and conclusions.

Amidst all this, presence of presuppositions was a key point. We took this availability and culpability of character traits behind the instances of implicata in their discourse as a tell-tale sign of a causal chain of elements linked together, and traced them back through a five-piece bottom-up process (see Figure 2), where implicata come from characters' utterances, which in turn arise from authors'/characters' making certain presuppositions, which are driven by characters' intended communicative intents, preferences and goals, which are directed by certain traits in the character. That most characters are intricate sets of traits attributable to humans warrants the claim that part of the planning goes for building communicative intents, preferences, and goals into the character. The planning and presupposing in turn back up the writer's implicating in the character's verbal discourse.

All this exploration of the mechanism that goes into the production and reception of implicata exchanges in literary text, by the writer and reader respectively, and the linkage between them and character traits led to the ultimate issue for this paper, as per which we argued that readers' interpretation of the text would vary should they pay conscious attention to certain areas we discussed. In precise words, while readers' subconscious attention to context, utterer's uncooperativeness, implicated premises, strongly-implicated premises, and related presuppositional grounds would only lead to achieving optimal relevance and a spontaneous interpretation, paying conscious attention to the stated areas as well as weakly-implicated conclusions and the character traits behind the implication would result in achieving maximal relevance, a non-spontaneous interpretation of the same implicature exchange and more cognitive effect, even though it is accompanied with spending considerably more processing effort on the reader's part.

\section{END NOTES}

1 Though 'utterance' is taken to be the phonological realization of language, it is aimed by authors of fiction to lead readers to believe they are vocally realized in the course a narrative when characters undertake verbal exchange.

\section{NOTES}

Note 1. The number of floutings listed may be extended as maxim flouting can, in very few cases, be viewed as prone to overlapping. For instance, what falls under the category of flouting the maxim of quantity by uttering more than is required could be taken account of as pertaining to flouting the maxim of manner, as well, for lack of required brevity.

Note 2. Use of 'flouting' has been preferred over other types on account of writers' presupposing and strategizing for implicating through character speech prior to the production.

Note 3 . As the writer is the one who makes utterances, it is $\mathrm{s} /$ he who stands in the position of the speaker and the reader, as the interpreter, takes the position of the hearer.

Note 4. The presuppositional grounds listed are liable to expansion. Our lists feature the mostly fundamental grounds.

Note 5 . Since all character discourse is produced by the writer, exchangeability is expected for the use of 'character' or 'writer' as the utterer.

Note 6. Use of 'help' is due here for character speech is only one medium of introducing, supporting or transforming traits within a character. As part of character and other-characters' speech, instances of implicating act merely as complementary agents to character action, character appearance, other-presentation, etc.

Note 7. Sample 1, being an instance of other-representation, does not follow the order above. In such a case, the trait(s) of the character spoken of (other character) addressed by the implicature replace the top-most stage of the process.

\section{REFERENCES}

Beaver, D.I. (2001). Presupposition and Assertion in Dynamic Semantics. Leland Stanford Jr. University.

Blakemore, D. (1992). Understanding Utterances. Cowley Rd, Oxford: Blackwell Publishers.

Chapman, S., \& Clark, B. (Eds) (2014). Pragmatic Literary Stylistics. Basingstoke, Hampshire: Palgrave Macmillan.

Cruse, D.A. (2000). Meaning in Language: An Introduction to Semantics and Pragmatics. Great Claredon St, Oxford: Oxford University Press.

Culpeper, J. (2001). Language and Characterization: People in Plays and Other Texts. New York, NY: Routledge. 
Davis, W.A. (1998). Implicature: Intention, Convention, and Principle in the Failure of Gricean Theory. The Edinburgh Building, Cambridge: Cambridge University Press.

Eder, J. et al. (2010). Characters in Fictional Worlds: Understanding Imaginary Beings in Literature, Film, and Other Media. Berlin: de Gruyter.

Furlong, A. (1996). Relevance Theory and Literary Interpretation (Doctoral Dissertation). London: University College London.

Geis, M.L. (1995). Speech Acts and Conversational Interactions. The Edinburgh Building, Cambridge: Cambridge University Press.

Grice, H.P. \& White, A.R. (1961). The Causal Theory of Perception. Proceedings of the Aristotelian Society 35 (suppl.), 121-52. doi:10.1093/aristoteliansupp/35.1.121

Grice, H.P. (1991). Studies in the Way of Words. Cambridge: Harvard University Press.

Johnstone, B. (2008). Discourse Analysis. Garsington Road. Oxford: Blackwell Publishing.

Levinson, S.C. (1983-2008). Pragmatics. The Edinburgh Building, Cambridge: Cambridge University Press.

Martin, P. (2004). Characterisation in the Novel: An Aesthetic of the Uncanny (Master's Thesis). School of Communications: Dublin City University.

McKee, R. (1997). Story: Substance, Structure, Style and the Principles of Screenwriting. East $53^{\text {rd }}$ St. New York: HarperCollins.
Portner, P. (2006). Meaning. In Fasold, R.W., \& Connor-Linton J. (Eds) (2006). An Introduction to Language and Linguistics. The Edinburgh Building, Cambridge: Cambridge University Press.

Rimmon-Kenan, Sh. (2005). Narrative Fiction (2 $2^{\text {nd }}$ edition). London: Routledge. doi: 10.4324/9780203426111

Roberts, E.V. (1995). Writing about Literature ( ${ }^{\text {th }}$ edition). Englewood Cliffs. New Jersey: Prentice Hall.

Schmitt, N. (2010). An Introduction to Applied Linguistics ( $2^{\text {nd }}$ edition). Euston Rd. London: Hodder Education.

Sperber, D., \& Wilson, D. (1995). Relevance: Communication and Cognition (2 $2^{\text {nd }}$ edition). Cowley Rd. Oxford: Blackwell Publishers.

Sperber, D., \& Wilson, D. (2002). Relevance Theory: A Tutorial. Proceedings of the Third Tokyo Conference on Psycholinguistics: 45-70.

Sperber, D., \& Wilson, D. (2006). Relevance Theory. In Horn, L. R., \& Ward G. (Eds), The Handbook of Pragmatics (pp. 607-632). Garrison Rd, Oxford: Blackwell.

Thomas, J. (2013). Meaning in Interaction: An Introduction to Pragmatics. New York, NY: Routledge.

Verschueren, J. (2003). Understanding Pragmatics. Euston Rd, London: Arnold.

Yule, G. (1996-2017). Pragmatics, Oxford Introductions to Language Study. Great Claredon Street, Oxford: Oxford University Press. 